\title{
Sulfane Sulfur Regulates LasR-Mediated Quorum Sensing and Virulence in Pseudomonas aeruginosa PAO1
}

\author{
Guanhua Xuan ${ }^{1,+}$, Chuanjuan Lv ${ }^{1,+}$, Huangwei Xu ${ }^{1}$, Kai Li ${ }^{1}$, Huaiwei Liu ${ }^{1} \mathbb{D}$, Yongzhen Xia ${ }^{1, * \mathbb{D}}$ \\ and Luying Xun $1,2, *$ (D)
}

1 State Key Laboratory of Microbial Technology, Shandong University, 72 Binhai Road, Qingdao 266237, China; xuanguanhua@ouc.edu.cn (G.X.); chuanjuanlv@sdu.edu.cn (C.L.); huangweixu@mail.sdu.edu.cn (H.X.); likai03721@sdu.edu.cn (K.L.); liuhuaiwei@sdu.edu.cn (H.L.)

2 School of Molecular Biosciences, Washington State University, Pullman, WA 99164-7520, USA

* Correspondence: xiayongzhen2002@email.sdu.edu.cn (Y.X.); luying_xun@vetmed.wsu.edu (L.X.); Tel.: +86-532-5863-1572 (Y.X.); +1-509-335-2787 (L.X.)

+ The authors contributed equally. C.L. started the research; G.X. completed the research.

check for updates

Citation: Xuan, G.; Lv, C.; Xu, H.; Li, K.; Liu, H.; Xia, Y.; Xun, L. Sulfane Sulfur Regulates LasR-Mediated Quorum Sensing and Virulence in Pseudomonas aeruginosa PAO1. Antioxidants 2021, 10, 1498. https://doi.org/10.3390/ antiox10091498

Academic Editors: João Vicente and Alessandro Giuffré

Received: 8 August 2021

Accepted: 18 September 2021

Published: 21 September 2021

Publisher's Note: MDPI stays neutral with regard to jurisdictional claims in published maps and institutional affiliations.

Copyright: (c) 2021 by the authors. Licensee MDPI, Basel, Switzerland. This article is an open access article distributed under the terms and conditions of the Creative Commons Attribution (CC BY) license (https:/ / creativecommons.org/licenses/by/ $4.0 /)$.

\begin{abstract}
Sulfane sulfur, such as inorganic and organic polysulfide $\left(\mathrm{HS}_{\mathrm{n}}{ }^{-}\right.$and $\left.\mathrm{RS}_{\mathrm{n}}{ }^{-}, n>2\right)$, is a common cellular component, produced either from hydrogen sulfide oxidation or cysteine metabolism. In Pseudomonas aeruginosa PAO1, LasR is a quorum sensing master regulator. After binding its autoinducer, LasR binds to its target DNA to activate the transcription of a suite of genes, including virulence factors. Herein, we report that the production of hydrogen sulfide and sulfane sulfur were positively correlated in P. aeruginosa PAO1, and sulfane sulfur was able to modify LasR, which generated $\mathrm{Cys}^{188}$ persulfide and trisulfide and produced a pentasulfur link between $\mathrm{Cys}^{201}$ and $\mathrm{Cys}^{203}$. The modifications did not affect LasR binding to its target DNA site, but made it several-fold more effective than unmodified LasR in activating transcription in both in vitro and in vivo assays. On the contrary, $\mathrm{H}_{2} \mathrm{O}_{2}$ inactivates LasR via producing a disulfide bond between Cys ${ }^{201}$ and Cys ${ }^{203}$. P. aeruginosa PAO1 had a high cellular sulfane sulfur and high LasR activity in the mid log phase and early stationary phase, but a low sulfane sulfur and low LasR activity in the declination phase. Thus, sulfane sulfur is a new signaling factor in the bacterium, adding another level of control over LasR-mediated quorum sensing and turning down the activity in old cells.
\end{abstract}

Keywords: quorum sensing; LasR; sulfane sulfur; signaling; protein persulfidation; virulence

\section{Introduction}

Hydrogen sulfide $\left(\mathrm{H}_{2} \mathrm{~S}\right)$ has been proposed as a new gaseous signaling molecule, mediating various biological functions in mammals, including humans [1-5]. Owing to its signaling role in eukaryotes, $\mathrm{H}_{2} \mathrm{~S}$ was suggested as a "clandestine microbial messenger" in 2006 [6]. Since then, several bacterial transcription factors, including FisR [7], SqrR [8], CstR [9], and CsoR [10], have been identified that indirectly respond to $\mathrm{H}_{2} \mathrm{~S}$, activating sulfur-oxidizing genes. First, sulfide:quinone oxidoreductase (SQR) converts $\mathrm{H}_{2} \mathrm{~S}$ to sulfane sulfur, including inorganic and organic polysulfide $\left(\mathrm{HS}_{\mathrm{n}}{ }^{-}\right.$and $\left.\mathrm{RS}_{\mathrm{n}}{ }^{-}, n \geq 2\right)$ and elemental sulfur $\left(S^{0}\right)[11,12]$. Sulfane sulfur is then sensed by these transcription factors to turn on the transcription of sulfur-oxidizing genes, including $p d o$ coding for persulfide dioxygenase (PDO). A synthetic gene circuit that combines SQR and CstR allows the host Escherichia coli to oxidize self-produced $\mathrm{H}_{2} \mathrm{~S}$ to sulfane sulfur and then sense the latter, resulting in gene regulation in a manner similar to quorum sensing (QS) [13]. These examples highlight how $\mathrm{H}_{2} \mathrm{~S}$ is converted by SQR to sulfane sulfur that is then sensed by these gene regulators.

Other gene regulators that are not involved in sulfur metabolism may also sense sulfane sulfur. OxyR, the $\mathrm{H}_{2} \mathrm{O}_{2}$-response gene regulator, senses cellular sulfane sulfur to turn on many genes, including those coding for the removal of excessive sulfane sulfur in E. coli [14]. MexR senses sulfane sulfur, which is maximally accumulated in late log phase by 
Pseudomonas aeruginosa PAO1, and activates the expression of a multidrug efflux pump for antibiotic resistance [15]. Additional examples are needed to confirm that $\mathrm{H}_{2} \mathrm{~S}$ and sulfane sulfur are common signaling molecules in bacteria, regulating diverse microbial behaviors.

Heterotrophic bacteria routinely produce $\mathrm{H}_{2} \mathrm{~S}$ and sulfane sulfur during normal growth $[16,17]$. L-Cysteine desulfhydrase directly converts L-cysteine to $\mathrm{H}_{2} \mathrm{~S}$ and pyruvate [18]. Other enzymes, such as cystathionine $\gamma$-lyase (CSE), cystathionine $\beta$-synthase (CBS), cysteinyl-tRNA synthetase, and 3-mercaptopyruvate sulfurtransferase (3-MST), metabolize L-cysteine and its derivatives to sulfane sulfur, which can be further reduced to $\mathrm{H}_{2} \mathrm{~S}$ [18-21]. $\mathrm{H}_{2} \mathrm{~S}$ can also be generated through the reduction of sulfite by sulfite reductase (CysI) during sulfite and sulfate assimilation [22]. For bacteria with sulfide:quinone oxidoreductases (SQR), such as P. aeruginosa PAO1, self-produced sulfide is oxidized back to sulfane sulfur [16]. Sulfane sulfur is a regular cellular component in the plasma and cells of mammals, as well as inside bacteria $[17,23]$. In bacteria, the concentration of sulfane sulfur can be higher than $100 \mu \mathrm{M}$ [17].

Pseudomonas aeruginosa is a ubiquitous Gram-negative bacterium and an opportunistic human pathogen [24]. P. aeruginosa strains are clinically significant, as several isolates are multidrug-resistant [25]. Various efforts, including using lavender essential oils, have been made to treat multidrug-resistant $P$. aeruginosa strains [26]. P. aeruginosa PAO1 has three QS systems, las, rhl, and pqs [27]. The QS systems regulate the expression of virulence factors, biofilm development, and production of secondary metabolites [28]. In the las system, LasI synthesizes the signal molecule $\mathrm{N}$-(3-oxododecanoyl)-L-homoserine lactone (3O- $\left.\mathrm{C}_{12}-\mathrm{HSL}\right)$. When LasR binds $3 \mathrm{O}-\mathrm{C}_{12}-\mathrm{HSL}$, it may bind to its targets, functioning as a transcription activator [29]. The las system regulates the rhl system that activates rhamnolipid biosynthesis and the pqs system, and the latter positively regulates pyocyanin biosynthesis [30-33]. Thus, LasR is a QS master regulator in P. aeruginosa PAO1.

Several factors affect LasR activity. The activity requires a threshold level of $3 \mathrm{O}-\mathrm{C}_{12}-\mathrm{HSL}$ [34]. However, the saturating level of $3 \mathrm{O}-\mathrm{C}_{12}-\mathrm{HSL}$ is not sufficient to fully induce the LasR regulon at low cell density [35-37]. Several proteins, e.g., QteE, QslA, and QscR, act to dampen gene activation by LasR [38], and some well-characterized LasR promoters use RpoS, a sigma factor for gene expression during the stationary phase [39]. The LasR activity is sensitive to oxidative stress [40]. Furthermore, surface association promotes the production of the small RNA Lrs1 that stimulates the production of LasR at low cell density [41]. Herein, we show that sulfide $\left(\mathrm{H}_{2} \mathrm{~S}, \mathrm{HS}^{-}\right.$, and $\left.\mathrm{S}_{2}{ }^{-}\right)$and sulfane sulfur also participate in LasR regulation in P. aeruginosa PAO1.

In this study, we deleted several genes involved in $\mathrm{H}_{2} \mathrm{~S}$ production and oxidation in P. aeruginosa $\mathrm{PAO} 1$. The $\mathrm{H}_{2} \mathrm{~S}$-oxidizing mutant did not show any apparent differences in growth from the wild type, but the $\mathrm{H}_{2} \mathrm{~S}$-producing mutant displayed a clear reduction of several virulence factors that are activated by LasR. RNA-seq also indicated that LasR was less active in the $\mathrm{H}_{2} \mathrm{~S}$-producing mutant than in the wild type. Further analysis showed that LasR activity was significantly enhanced by sulfane sulfur, which was high in the mid $\log$ phase to stationary phase of growth. In the declination phase, cellular sulfane sulfur level became low, which was associated with significantly low LasR activity.

\section{Materials and Methods}

\subsection{Strains, Plasmids, and Reagents}

The strains and plasmids used in this work are listed in Table S1. Unless noted otherwise, P. aeruginosa PAO1 and its derivatives were grown in lysogeny broth (LB) medium or Pseudomonas broth (PB) (2\% Bacto-peptone, $0.14 \% \mathrm{MgCl}_{2}, 1 \% \mathrm{~K}_{2} \mathrm{SO}_{4}, 2 \%$ glycerol) medium at $37^{\circ} \mathrm{C}$ [42]. Kanamycin $(50 \mu \mathrm{g} / \mathrm{mL})$, ampicillin $(100 \mu \mathrm{g} / \mathrm{mL})$, or gentamicin $(30 \mu \mathrm{g} / \mathrm{mL})$ was added when required. Other chemicals such as $\mathrm{NaHS}\left(\mathrm{H}_{2} \mathrm{~S}\right.$ donor) and $3 \mathrm{O}-\mathrm{C}_{12}-\mathrm{HSL}$ were purchased from Sigma-Aldrich. $\mathrm{HS}_{\mathrm{n}}{ }^{-}$was prepared following a reported method [43], and the stock concentration was determined using a cyanolysis method and calibrated by using thiosulfate as the standard [43]. 


\subsection{Gene Knockout and Complementation}

The primers used for Pacbs, Pacse, Pamst, PacysI, Pasqr1, Pasqr2, Papdo, and PalasR inactivation are listed in Table S2. The deletions in P. aeruginosa PAO1 were performed according to a published method [44,45]. Briefly, about 1000-bp fragments upstream and downstream of the target gene were amplified from the PAO1 genomic DNA via PCR, linked, and cloned into pK18mobsacB $B_{\text {tet }}$ at the EcoRI site. The resulting plasmid was first transformed into E. coli and then transferred into P. aeruginosa PAO1 via conjugation. The integration into the chromosome of $P$. aeruginosa PAO1 by a homologous crossover was selected on agar plates of a chemically defined medium, with sodium gluconate as the sole carbon source containing tetracycline. The selection of the double crossover with $12 \%$ sucrose led to gene-deletion. For multiple deletions, the process was repeated. The deletion mutants, including $\mathrm{Pa} \Delta c b s \Delta c s e \Delta m s t \Delta c y s I \Delta$ sqr $1 \Delta s q r 2 \Delta p d o$ (Pa7K), Pa $\Delta$ cbs $\Delta c s e \Delta m s t \Delta c y s I$ $\left(\mathrm{Pa} \Delta \mathrm{H}_{2} \mathrm{~S}\right), \mathrm{Pa} \Delta$ sqr $1 \Delta$ sqr $2 \Delta$ do $(\mathrm{Pa} 3 \mathrm{~K})$, and $\mathrm{Pa} \Delta$ las $\mathrm{R}$, were confirmed by using colony $\mathrm{PCR}$ and DNA sequencing. For complementation, the target genes were amplified by PCR and cloned into linearized pBBR1MCS5 by using an In-Fusion HD cloning kit (Clontech, Mountain View, CA, USA). The resulting plasmids were then transferred into the PAO1 strain via electroporation.

\subsection{Detection of $\mathrm{H}_{2} \mathrm{~S}$ and Sulfane Sulfur}

The production of $\mathrm{H}_{2} \mathrm{~S}$ by PAO1 and its related mutant strains was detected with a paper strip with lead-acetate $\left[\mathrm{Pb}(\mathrm{Ac})_{2}\right]$ (Shanghai, China) and a monobromobimane $(\mathrm{mBBr})$ method [46]. Briefly, single colonies were innoculated in $2 \mathrm{~mL}$ of LB medium in a 15-mL glass tube, and a paper strip with lead-acetate was affixed at the top of the tube with a rubber stopper. The paper strip was examined and photographed to detect any lead(II)-sulfide black precipitates, indicting the production of $\mathrm{H}_{2} \mathrm{~S}$. $\mathrm{H}_{2} \mathrm{~S}$ in the liquid culture was detected using the $\mathrm{mBBr}$ method [46]. Briefly, $5 \mu \mathrm{L}$ of $25 \mathrm{mM} \mathrm{mBBr}$ was reacted with $50 \mu \mathrm{L}$ of a sample at room temperature for $30 \mathrm{~min}$ in the dark, and an equal volume of $10 \%$ acetic acid in acetonitrile was added. The samples were centrifuged at 12,500 $\times g$ for $2 \mathrm{~min}$ and the supernatant was analyzed using HPLC (LC-10AT, Shimadzu) with a fluorescence detector, as reported [11].

SSP4 (sulfane sulfur probe 4, 3', 6'-di(O-thiosalicyl)fluorecein) that reacts with sulfane sulfur to become fluorescent was used to check the relative levels of cellular sulfane sulfur in P. aeruginosa cells [47]. The cells were collected, washed with phosphate buffer saline, and resuspended in phosphate buffer saline at an $\mathrm{OD}_{600 \mathrm{~nm}}$ of 1 . Then $10 \mu \mathrm{M} \mathrm{SSP} 4$ and $0.5 \mathrm{mM}$ hexadecyltrimethylammonium bromide (CTAB) were added to the sample, which was incubated in the dark at $30{ }^{\circ} \mathrm{C}$, with shaking for $20 \mathrm{~min}$. Cells were harvested by centrifugation and washed twice with phosphate buffer saline. The fluorescence of the resuspended cells $\left(\mathrm{OD}_{600 \mathrm{~nm}}=1\right)$ was detected by using a Synergy H1 microplate reader with excitation of $482 \mathrm{~nm}$ and emission of $515 \mathrm{~nm}$. We were unable to quantify sulfane sulfur with SSP4. For quantification, cellular sulfane sulfur in P. aeruginosa PAO1 at different growth stages was reacted with sulfite to produce thiosulfate, which was then quantified according to a reported method [17]. Briefly, samples were mixed with the reaction buffer with sulfite to convert sulfane sulfur to thiosulfate by incubating at $95^{\circ} \mathrm{C}$ for $20 \mathrm{~min}$; buffer without sulfite was used as the control. The produced thiosulfate was detected by using the $\mathrm{mBBr}$ method [46], as briefly described above.

\subsection{Rhamnolipids Production Measurement}

Rhamnolipid production was measured by following a reported method [48]. Briefly, $5 \mu \mathrm{L}$ of an overnight culture was placed onto a M8 minimal agar plate supplemented with $0.0005 \%(\mathrm{~m} / \mathrm{v})$ methylene blue and $0.02 \%(\mathrm{~m} / \mathrm{v}) \mathrm{CTAB}$; the plate was incubated at $37^{\circ} \mathrm{C}$ for $48 \mathrm{~h}$ before checking for the clear zone around a colony. For the $\mathrm{H}_{2} \mathrm{~S}$ supplemental experiment, 10 drops of $1 \mathrm{mM} \mathrm{NaHS}$ in $\mathrm{H}_{2} \mathrm{O}$ were separately dropped on the plate cover. The plates were inverted, and $\mathrm{H}_{2} \mathrm{~S}$ entered the medium via evaporation. 


\subsection{Pyocyanin Quantitation Assay}

Pyocyanin concentration was determined by using a reported method [42]. Briefly, strains were grown at $37^{\circ} \mathrm{C}$ in $5 \mathrm{~mL}$ of $\mathrm{PB}$ medium to stationary phase. The culture supernatants were extracted with $3 \mathrm{~mL}$ of chloroform, which was mixed with $1 \mathrm{~mL}$ of $0.2 \mathrm{M}$ $\mathrm{HCl}$ to develop a pink to deep red color in the organic phase for measurements at $520 \mathrm{~nm}$. The concentration was calculated and normalized to the cell density $\left(\mathrm{OD}_{600 \mathrm{~nm}}\right)$.

\subsection{Lettuce Leaf Model of Infection}

A lettuce leaf virulence assay was performed, as described [48,49]. Briefly, P. aeruginosa strains were grown in $\mathrm{PB}$ medium at $37^{\circ} \mathrm{C}$ overnight with shaking $(200 \mathrm{rpm})$; the cells were harvested, washed, and resuspended in sterile $10 \mathrm{mM} \mathrm{MgSO}_{4}$ to a bacterial density of $1 \times 10^{9}$ cells $/ \mathrm{mL}$. Romaine lettuce leaves were washed with sterile distilled $\mathrm{H}_{2} \mathrm{O}$ with $0.1 \%$ bleach and then inoculated with the strains on the midribs of the leaves, which were placed in containers underlined with wet filter paper containing $10 \mathrm{mM} \mathrm{MgSO}_{4}$. The inoculated leaves were kept in a growth chamber at $37^{\circ} \mathrm{C}$. Symptoms were monitored daily. As a control, lettuce leaves were inoculated with $10 \mathrm{mM} \mathrm{MgSO}_{4}$.

\subsection{Transcriptomic Analysis of $\mathrm{PAO}$ and $\mathrm{Pa} \Delta \mathrm{H}_{2} \mathrm{~S}$}

For transcriptome sequencing (RNA-seq) analysis, $\mathrm{PAO} 1$ and $\mathrm{Pa} \Delta \mathrm{H}_{2} \mathrm{~S}$ were cultured in $\mathrm{PB}$ medium at $37^{\circ} \mathrm{C}$ with shaking at $200 \mathrm{rpm}$ to late $\log$ phase. Cells were centrifuged, and the pellets were frozen in liquid nitrogen, and shipped on dry ice to Beijing Novogene Bioinformatics Technology Co., Ltd. (Beijing, China). The subsequent analysis was made by the company. Total RNA was extracted by using a TRIzol ${ }^{\mathrm{TM}}$ RNA Purification Kit (12183555, Invitrogen, Waltham, MA USA). Then, $3 \mu \mathrm{g}$ of total RNA was treated with a Ribo-Zero rRNA Removal Kit (MRZMB 126, Epicentre Biotechnologies). First-strand cDNA was synthesized by using random hexamer primers and M-MuLV Reverse Transcriptase, and second-strand cDNA synthesis was subsequently performed by using DNA polymerase I. RNase $\mathrm{H}$ was used to remove RNA. NEBNext index adaptor oligonucleotides were ligated to the cDNA fragments. The cDNA fragments of 150-200 bp in length were purified and amplified via PCR with universal PCR primer and index $(X)$ primer. The library was quantified using an Agilent High Sensitivity DNA assay on an Agilent 267 Bioanalyzer 2100 system and sequenced on the Illumina Hiseq 2500 platform. Trimmed sequence reads were aligned to the P. aeruginosa PAO1 genome sequence using Bowtie2-2.2.3. Gene expression was analyzed with the reads per kilobase of coding sequence per million reads (RPKM) algorithm. Differential expression analysis of the two strains was performed using the DESeq R package (1.18.0). Genes with a change fold $>2$ and a $p$-value $<0.05$ were considered as significantly differentially expressed.

\subsection{Reporter Plasmids Construction and Fluorescence Assays}

Red fluorescence protein (mkate) reporter assays-E. coli BL21(DE3) cells were transformed with a plasmid derived from Ptrc99a, containing lasR, the promoter of $r h l R$, and mkate (Ptrc- $P_{\text {lacl }}$-las $\left.R-P_{\text {rhlR }}-m k a t e\right)$. Site-directed mutagenesis to convert lasR Cys ${ }^{79}, \mathrm{Cys}^{188}$, $\mathrm{Cys}^{201}$, and $\mathrm{Cys}^{203}$ to serine was achieved according to a reported method [50]. All primers used in the experiments are listed in Table S2. Using this reporter strain, LasR activity was quantified. Starting with a 1/1000-fold dilution of an overnight culture, the reporter strain was grown in LB medium supplemented with $20 \mu \mathrm{M} 3 \mathrm{O}-\mathrm{C}_{12}-\mathrm{HSL}$ and ampicillin $(100 \mu \mathrm{g} / \mathrm{mL})$ at $37^{\circ} \mathrm{C}$ with shaking. When cultures were grown to an $\mathrm{OD}_{600 \mathrm{~nm}}$ of $2,300 \mu \mathrm{M}$, polysulfide was added. After incubating at $37^{\circ} \mathrm{C}$ for an additional $2 \mathrm{~h}$ to produce mkate, $0.2 \mathrm{~mL}$ of the cells was transferred to a 96-well plate and the mkate fluorescence was measured by using a SynergyH1 microplate reader. The excitation wavelength was set at $588 \mathrm{~nm}$ and the emission wavelength was set at $633 \mathrm{~nm}$. 


\subsection{Protein Expression and Purification}

E. coli BL21(DE3) carrying the expression plasmid PET30-LasR was grown in LB to an $\mathrm{OD}_{600 \mathrm{~nm}}$ of $0.4-0.6$, IPTG was added to $0.1 \mathrm{mM}$. Growth was continued at $18{ }^{\circ} \mathrm{C}$, overnight. Cells were harvested by centrifugation, washed twice with ice-cold lysis buffer $(50 \mathrm{mM}$ $\mathrm{NaH}_{2} \mathrm{PO}_{4}, 300 \mathrm{mM} \mathrm{NaCl}$ and $20 \mathrm{mM}$ imidazole, $\mathrm{pH}$ 8.0), and disrupted using a high pressure crusher SPCH-18 (STANSTED). The sample was centrifuged and the supernatant was loaded onto nickel-nitrilotriacetic acid (Ni-NTA) agarose resin (Invitrogen). The target protein was purified according to the supplier's recommendations. The eluted protein was loaded onto PD-10 column (GE) for buffer exchange to $20 \mathrm{mM}$ sodium phosphate buffer ( $\mathrm{pH}$ 7.6). The purity of the proteins was checked via SDS-PAGE.

\subsection{Electrophoretic Mobility Shift Assay (EMSA)}

A 300-bp DNA probe containing the rhlR promoter sequence was obtained using PCR from the genomic DNA. For quantitative binding assays, different amounts of purified LasR, DNA probe, and binding buffer ( $10 \mathrm{mM}$ Tris, $50 \mathrm{mM} \mathrm{KCl}, 5 \%$ glycerin, $\mathrm{pH} 8.0)$ were mixed and incubated at $30{ }^{\circ} \mathrm{C}$ for $30 \mathrm{~min}$. The reaction mixture was then loaded onto a $6 \%$ native polyacrylamide gel and electrophoresed at $180 \mathrm{~V}$ for $1.5 \mathrm{~h}$. The gel was subsequently stained with SYBR green I and photographed with a FlourChemQ system (Alpha Innotech, San Jose, CA USA). For EMSA experiments, LasR purification was done in an anaerobic glove box (YQX-II, Xinmiao Medical Instruments, Shanghai, China), filled with a gas mixture $\left(85 \% \mathrm{~N}_{2}, 10 \% \mathrm{H}_{2}\right.$, and $\left.5 \% \mathrm{CO}_{2}\right)$. The $\mathrm{O}_{2}$ level was maintained at $<0.1 \%$ via palladium catalysis of $\mathrm{H}_{2}$ reaction with $\mathrm{O}_{2}$ and monitored using gas a detector (ADKS-4, EDKORS, Changzhou, China). The buffers for LasR purification were all degassed, and $10 \mathrm{mM}$ dithiothreitol (DTT) was added, when necessary, and removed by passing a PD-10 desalting column before $\mathrm{HS}_{\mathrm{n}}{ }^{-}$treatment.

\subsection{In Vitro Transcription-Translation Analysis}

An S30 T7 High-Yield Protein Expression System (Promega \#L1110) was used for in vitro transcription-translation analysis. The reactions contained $20 \mu \mathrm{L}$ of S30 Premix Plus, $18 \mu \mathrm{L}$ of T7 S30 extract, $2 \mu \mathrm{L}$ of E. coli RNA polymerase (NEB \#M0551), $1 \mu \mathrm{L}$ of RNase inhibitor, 500 ng of DNA template containing $P_{\text {rhlR }}$-mkate, and $800 \mathrm{ng}$ of LasR; RNase-free water was added to bring the volume to $50 \mu \mathrm{L}$. LasR was used as untreated, $160 \mu \mathrm{M}$ $\mathrm{HS}_{\mathrm{n}}{ }^{-}$-treated, and $\mathrm{HS}_{\mathrm{n}}{ }^{-}$-treated LasR, which was then reduced by $30 \mathrm{mM}$ DTT. After being incubated with vigorous shaking at $37^{\circ} \mathrm{C}$ for $2 \mathrm{~h}$, the translated mkate was diluted and assayed by using an Synergy $\mathrm{H} 1$ microplate reader. The excitation wavelength was set at $588 \mathrm{~nm}$, and the emission wavelength was set at $633 \mathrm{~nm}$. Fluorescence intensities from other groups were divided by that of the untreated LasR to calculate the relative expression levels.

\subsection{LC-MS/MS Analysis of LasR}

Three samples, untreated LasR, $\mathrm{HS}_{\mathrm{n}}{ }^{-}$-treated LasR, and DTT-treated LasR, were prepared for mass spectral analysis. Untreated LasR was used as purified and diluted to $1 \mu \mathrm{g} / \mu \mathrm{L}$ in the $20 \mathrm{mM}$ phosphate buffer ( $\mathrm{pH}$ 7.6). For DTT-treated LasR, $1 \mathrm{~mL}$ of the purified LasR was reacted with $30 \mu \mathrm{L}$ of $1 \mathrm{M}$ DTT. For $\mathrm{HS}_{\mathrm{n}}{ }^{-}$-treated LasR, $1 \mathrm{~mL}$ of the purified LasR $(1 \mu \mathrm{g} / \mu \mathrm{L})$ was mixed with $8 \mu \mathrm{L}$ of $20 \mathrm{mM}$ polysulfide. All the samples were incubated at room temperature for $1 \mathrm{~h}$. Then denaturing buffer $(0.5 \mathrm{M}$ Tris-HCl, $2.75 \mathrm{mM}$ EDTA, $6 \mathrm{M}$ guanidine- $\mathrm{HCl}, \mathrm{pH}$ 8.1) and iodoacetamide (IAM) were added to denaturalize LasR and block free thiols. Samples were digested by trypsin (Promega) for $12 \mathrm{~h}$ at $37{ }^{\circ} \mathrm{C}$ and were subjected to $\mathrm{C} 18 \mathrm{Zip}$-Tip (Millipore) purification for desalting before analysis by HPLC- tandem mass spectrometry (LC-MS) using a Prominence nano-LC system (Shimadzu, Nishinokyo, Japan) and LTQ-OrbitrapVelos Pro CID mass spectrometer (Thermo Scientific, Waltham, MA, USA). A linear gradient of solvent A ( $0.1 \%$ formic acid in $2 \%$ acetonitrile) and solvent B (0.1\% formic acid in 98\% acetonitrile) from $0 \%$ to $100 \%$ 
of solvent B in 100 min was used for elution. Full-scan MS spectra (from 400 to $1800 \mathrm{~m} / \mathrm{z}$ ) were detected with a resolution of 60,000 at $400 \mathrm{~m} / \mathrm{z}$.

\subsection{Real-Time Quantitative Reverse Transcription PCR (RT-qPCR)}

For RT-qPCR, the cells were collected at a defined incubation time, total RNA was extracted by using a TRIzol ${ }^{\mathrm{TM}}$ RNA Purification Kit (12183555, Invitrogen), and cDNA was synthesized by the HiScript ${ }^{\circledR}$ II Reverse Transcriptase (Vazyme, Nanjing, China). RT-qPCR was performed by using a Bestar SybrGreen qPCR Mastermix (DBI Bioscience, Shanghai, China) and LightCycler 480II (Roche, Penzberg, Germany). For calculation of the relative expression levels of tested genes, rplS was used as the reference gene.

\section{Results}

\section{1. $\mathrm{H}_{2} \mathrm{~S}$ and Sulfane Sulfur Production by P. aeruginosa PAO1 and Its Mutants}

P. aeruginosa PAO1 contains two sqr genes (Pasqr1 and Pasqr2) and one pdo (Papdo) [16]. In LB medium, the wild type did not release $\mathrm{H}_{2} \mathrm{~S}$, but its mutant ( $\left.\mathrm{Pa} 3 \mathrm{~K}\right)$ with the three $\mathrm{H}_{2} \mathrm{~S}$-metabolic genes (sqr1, sqr2, and pdo) being knocked out released $\mathrm{H}_{2} \mathrm{~S}$, as detected by filter paper strips containing lead acetate in the gas phase (Figure 1A). P. aeruginosa PAO1 also contains four genes (cbs, cse, $m s t$, and cysI) capable of producing $\mathrm{H}_{2} \mathrm{~S}$. The four genes were deleted from PAO1 and $\mathrm{Pa} 3 \mathrm{~K}$ to generate $\mathrm{Pa} \Delta \mathrm{H}_{2} \mathrm{~S}$ and $\mathrm{Pa} \mathrm{K}$, respectively; both mutants did not release detectable $\mathrm{H}_{2} \mathrm{~S}$ into the gas phase (Figure 1A). However, there was trace sulfide detectable by using the $\mathrm{mBBr}$ method in the culture supernatants of the mutants (Figure S1). Intracellular sulfane sulfur was detected with SSP4. $\mathrm{Pa} \Delta \mathrm{H}_{2} \mathrm{~S}$ and $\mathrm{Pa} 7 \mathrm{~K}$ clearly contained less sulfane sulfur than PAO1 and Pa3K, especially at $24 \mathrm{~h}$ of culturing in LB medium (Figure 1B). The mutants grew equally well compared to the wild type in LB medium. The results indicate that CBS, CSE, MST, and CysI are involved in generating $\mathrm{H}_{2} \mathrm{~S}$ and intracellular sulfane sulfur, and the produced $\mathrm{H}_{2} \mathrm{~S}$ is oxidized by SQR and PDO.

A

PAO1 $\mathrm{Pa} \Delta \mathrm{H}_{2} \mathrm{~S} \quad \mathrm{~Pa} 3 \mathrm{~K} \quad \mathrm{~Pa} 7 \mathrm{~K}$

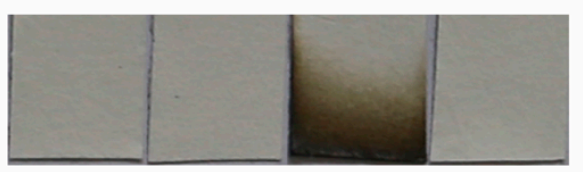

B

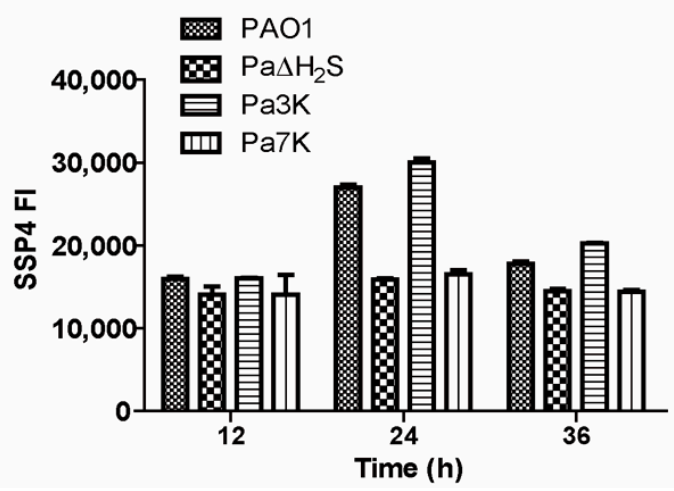

Figure 1. The production of $\mathrm{H}_{2} \mathrm{~S}$ and sulfane sulfur in P. aeruginosa PAO1 and its mutants. (A) Lead-acetate paper strips were used to detect $\mathrm{H}_{2} \mathrm{~S}$ in the gas phase during the growth of PAO1 and its mutants in LB medium for $48 \mathrm{~h}$. (B) The levels of sulfane sulfur in PAO1 and its mutants were monitored by SSP4 fluorescence.

\subsection{Virulence Factors and Pathogenicity of PAO1 and Its Mutant Strains}

The production of two virulence factors, rhamnolipids and pyocyanin, by P. aeruginosa PAO1 and its mutants was assayed. The deletion of $\mathrm{H}_{2} \mathrm{~S}$-oxidizing genes did not affect the production of rhamnolipids and pyocyanin, but the deletion of $\mathrm{H}_{2} \mathrm{~S}$-producing genes 
decreased, obviously, the production of rhamnolipids and pyocyanin. $\mathrm{Pa} \Delta \mathrm{H}_{2} \mathrm{~S}$ and $\mathrm{Pa} / \mathrm{K}$ restored rhamnolipid production with added sulfide, implying that $\mathrm{H}_{2} \mathrm{~S}$ participates in the regulation of the production of virulence factors in PAO1 (Figure 2A-D). The deletion of $\mathrm{H}_{2} \mathrm{~S}$-producing genes also decreased the pathogenicity, as $\mathrm{Pa} \Delta \mathrm{H}_{2} \mathrm{~S}$ and Pa7K almost lost the ability to infect lettuce leaves (Figure 2E).

A

CTAB plate

B

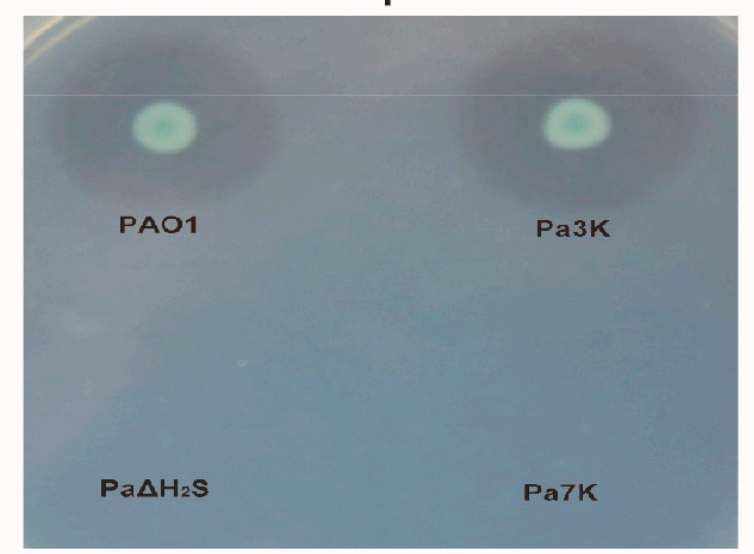

CTAB plate $+\mathrm{H}_{2} \mathrm{~S}$
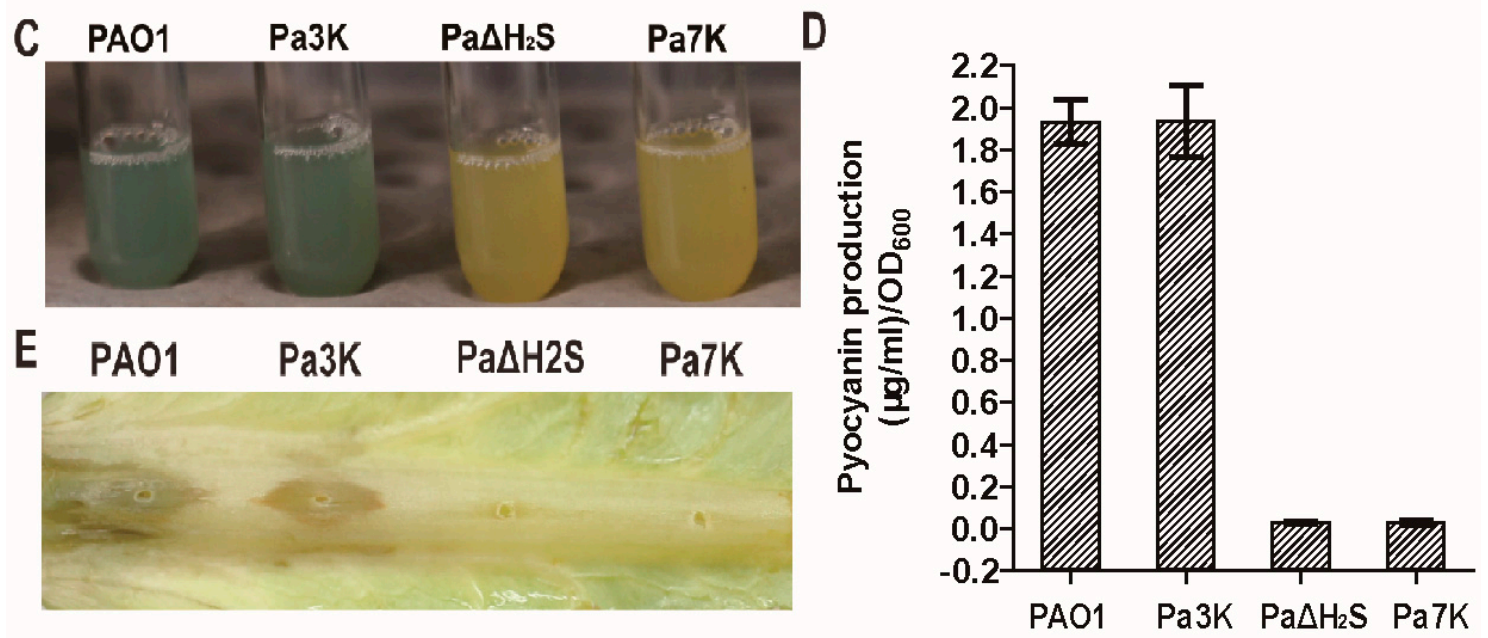

Figure 2. The production of virulence factors by PAO1 and its mutants. (A) Rhamnolipid production (clear zone) by PAO1 and its mutants cultured on a CTAB plate. (B) Rhamnolipid production by PAO1 and its mutants cultured on a CTAB plate with NaHS being added on the inverted lid. (C) Pictures of the cultures of PAO1 and its mutants in PB medium at $37^{\circ} \mathrm{C}$ and stationary phase. The green was due to pyocyanin. (D) Spectrophotometric quantitation of extracted pyocyanin from the culture supernatants $(\mathbf{C})$. Data are averages of three experiments with standard deviations. (E) Infection of PAO1 and its mutants on lettuce.

\subsection{Linking $\mathrm{H}_{2} \mathrm{~S} /$ Sulfane Sulfur to LasR}

The RNA-seq results showed that $>3000$ genes were differentially expressed in PAO1 and $\mathrm{Pa} \Delta \mathrm{H}_{2} \mathrm{~S}$, indicating that $\mathrm{H}_{2} \mathrm{~S}$ has an immense influence on PAO1 gene expression (Figure S2). The genes related to the production of rhamnolipid and pyocyanin were clearly suppressed in $\mathrm{Pa} \Delta \mathrm{H}_{2} \mathrm{~S}$, relative to PAO1, consistent with the observed phenotypes. The potential role of LasR in regulating RhlR and PqsR that control the production of rhamnolipids and pyocyanin was noticed, as the related genes were downregulated in $\mathrm{Pa} \Delta \mathrm{H}_{2} \mathrm{~S}$ (Table S3). Upregulated genes are summarized in Table $\mathrm{S} 4$ and were dominated by transporters and hypothetical proteins. PAO1 lasR null mutant $(\mathrm{Pa} \Delta l a s R)$ grew as well as the wild type in LB (Figure S3A), but it decreased infection on the lettuce leaves (Figure S3B). 


\subsection{LasR Senses $\mathrm{H}_{2} \mathrm{~S}$ through Sulfane Sulfur}

The transcription regulator LasR binds to specific DNA sequences, called lux boxes [30,32]. We constructed a reporter plasmid Ptrc- $P_{\text {lacI }}-l a s R-P_{\text {rhlR }}-m k a t e$, containing the lux box of the rhlR upstream region fused to mkate, and introduced it into E. coli BL21(DE3). The induction required $3 \mathrm{O}-\mathrm{C}_{12}-\mathrm{HSL}$ [40], and the addition of NaHS did not enhance the mkate expression (Figure 3A). However, the addition of $\mathrm{HS}_{\mathrm{n}}{ }^{-}$significantly enhanced the production of mkate (Figure 3B). Furthermore, when $\mathrm{SQR}$, which converts $\mathrm{H}_{2} \mathrm{~S}$ to sulfane sulfur [51], was also cloned into E. coli containing the reporter system, the addition of $\mathrm{NaHS}$ enhanced the mkate expression (Figure 3A). The results indicate that LasR does not directly sense $\mathrm{H}_{2} \mathrm{~S}$, but senses sulfane sulfur.

A

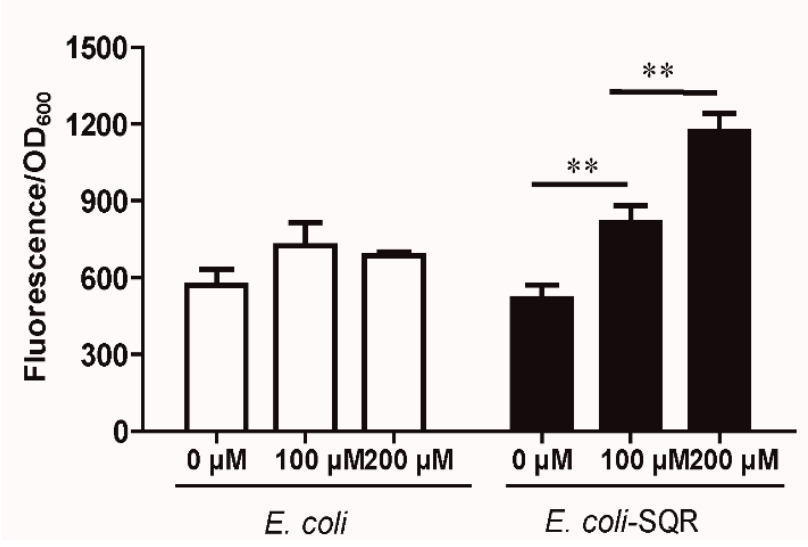

B

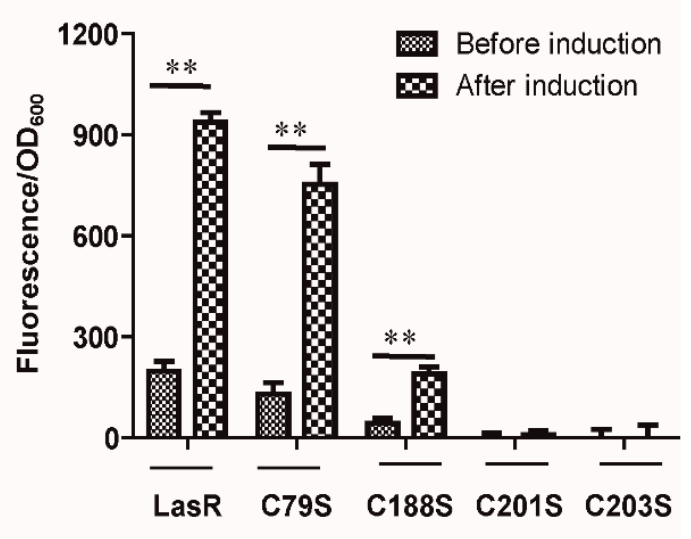

Figure 3. The expression of $m k$ ate from $P_{\text {rhlR }}$ via LasR activation was significantly enhanced by sulfane sulfur. (A) E. coli (pTrc- $P_{\text {lac }}$-lasR-P $P_{\text {rhlR }}$-mkate)(pBBR1mcs2) or E. coli (pTrc- $P_{\text {lac }}$-lasR- $P_{\text {rhlR }}$-mkate)(pBBR1mcs2-SQR) was treated by adding 0 , 100, or $200 \mu \mathrm{M}$ NaHS. Kanamycin and ampicillin were added to maintain the plasmids. (B) E. coli (pTrc-PlacI-lasR-P rhlR-mkate) containing LasR or its mutant with the Cys mutation was treated with $300 \mu \mathrm{M} \mathrm{HS}_{\mathrm{n}}{ }^{-}$. Ampicillin was added to maintain the plasmid. The E. coli cells were culture in LB medium containing $20 \mu \mathrm{M} 3 \mathrm{O}-\mathrm{C}_{12}-\mathrm{HSL}$, while the control contained no $3 \mathrm{O}-\mathrm{C}_{12}$-HSL. The background fluorescence of the control was subtracted. Data are averages and standard deviations of three experiments. T-tests were performed. ${ }^{* *}$ indicates that the samples were significantly different $(p<0.01)$.

LasR contains four cysteine residues $\left(\mathrm{Cys}^{79}, \mathrm{Cys}^{188}, \mathrm{Cys}^{201}\right.$, and $\left.\mathrm{Cys}{ }^{203}\right)$. They were individually mutated into serine in the reporter plasmid Ptrc- $P_{\text {lac }}-$ las $R-P_{\text {rhlR }}-m k a t e$, producing Ptrc- $P_{\text {lac }}$-lasR/C79S-P $P_{\text {rhlR }}-m k$ kate, Ptrc- $P_{\text {lac }}$-lasR/C188S- $P_{\text {rhlR }}$-mkate, Ptrc- $P_{\text {lacI }}$-lasR/C201S$P_{\text {rhlR }}-m k a t e$, and Ptrc- $P_{\text {lacl }}$-lasR/C203S- $P_{\text {rhlR }}$-mkate. C79S had a limited effect, C188S had a large reduction in activity, and C201S and C203S were inactive (Figure 3B).

\subsection{Characterization of LasR Modification}

LasR was purified with $3 \mathrm{O}-\mathrm{C}_{12}$-HSL because this apoprotein is insoluble [29,52]. An electrophoretic mobility shift assay (EMSA) showed that $\mathrm{HS}_{\mathrm{n}}{ }^{-}$-treated LasR did not affect its binding to target DNA (Figure 4). However, the $\mathrm{HS}_{\mathrm{n}}{ }^{-}$-treated LasR had a 3.4-fold higher expression of the mkate gene than DTT-treated or untreated LasR in a coupled transcription and translation assay (Figure 5), in agreement with the whole-cell reporter assay (Figure 3). These results suggest that the $\mathrm{HS}_{n}{ }^{-}$-modified LasR is more effective when working with RNA polymerase to initiate transcription. 
A

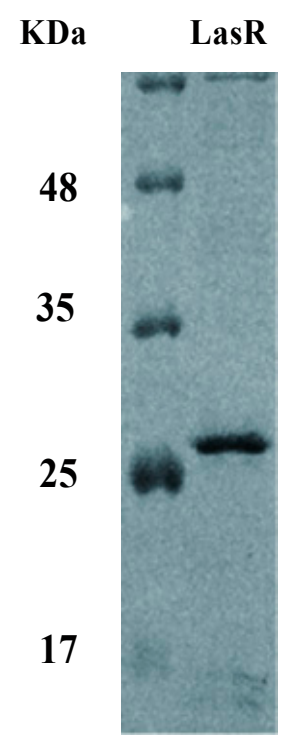

B LasR
$\begin{array}{llllllllll}M & 0.16 & 0.32 & 0.48 & 0.64 & 0.8 & 0.96 & 1.2 & 1.6 & (\mu M)\end{array}$

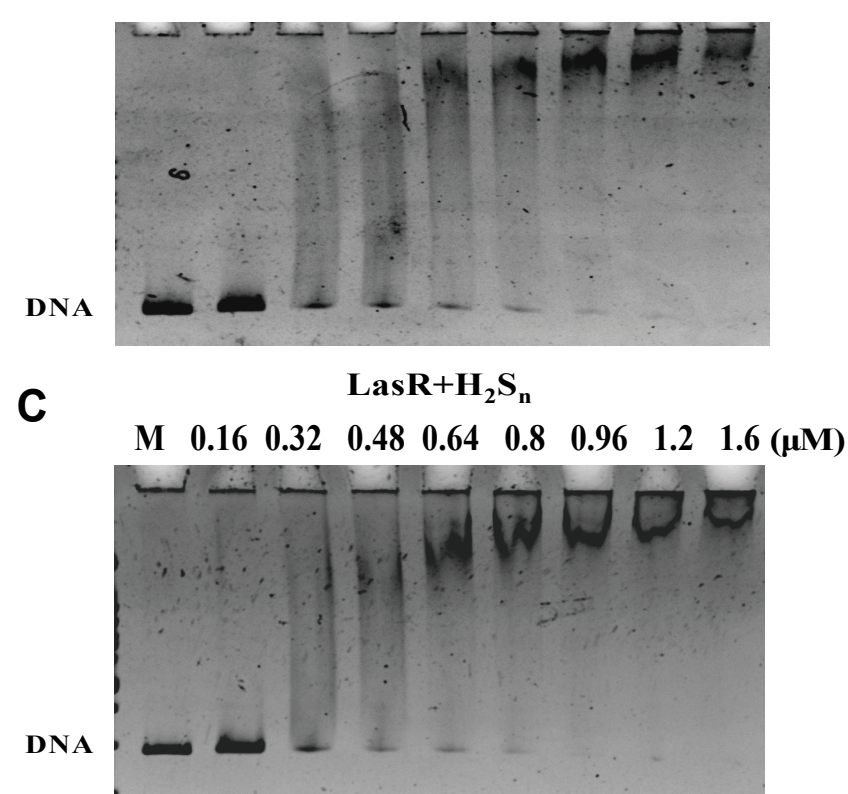

Figure 4. Impact of sulfane sufur on LasR binding to DNA. (A) SDS analysis of purified LasR. EMSA analysis of LasR (B) and $\mathrm{HS}_{\mathrm{n}}{ }^{-}$-treated LasR $(\mathbf{C})$ under anaerobic conditions in the presence of a DNA probe $(8 \mathrm{nM})$ containing the LasR-binding sequence $\left(\mathrm{P}_{r h l R}\right)$.

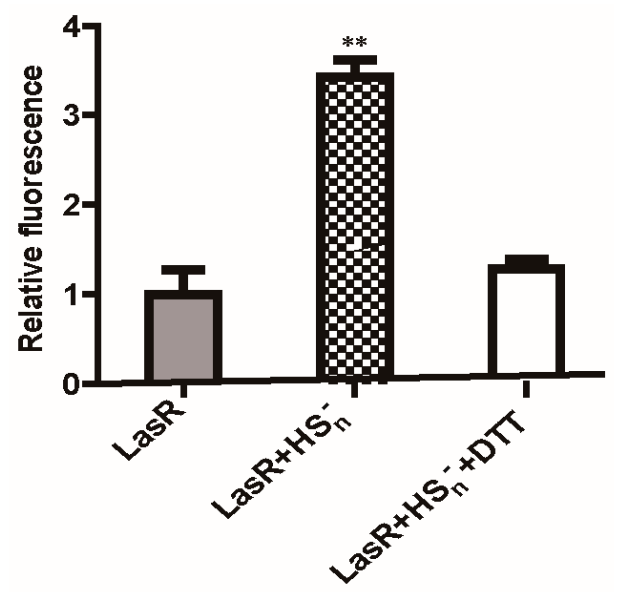

Figure 5. In vitro transcription-translation analysis of LasR activity. Purified LasR, $\mathrm{HS}_{\mathrm{n}}{ }^{-}$-treated LasR, and $\mathrm{HS}_{\mathrm{n}}{ }^{-}$treated LasR that was then reduced by DTT were used to initiate the transcription and translation from a DNA template containing $\mathrm{P}_{r h l R}$-mkate. The produced fluorescent protein, mkate, was detected via its fluorescence. Data are averages of three experiments with standard deviations. T-tests were performed. ${ }^{* *}$ indicates that the sample was significantly different from untreated LasR $(p<0.01)$.

\section{6. $\mathrm{HS}_{n}{ }^{-}$Modifies Cys ${ }^{188}, \mathrm{Cys}^{201}$, and $\mathrm{Cys}^{203}$ of LasR}

In DTT-treated LasR, Cys ${ }^{188}$ in Peptide $1 \mathrm{a}$ and Cys ${ }^{201}$, and Cys ${ }^{203}$ in Peptide 2a were unmodified (Figure 6, Figure S4A and Figure S6A). The thiol groups were blocked by iodoacetamide, indicating that Peptide $1 \mathrm{a}$ and Peptide $2 \mathrm{a}$ were unmodified. A small fraction of the oxidized form (Figure 6 and Figure S4B, Peptide 1b) containing Cys ${ }^{188}$-SOH was present in untreated LasR and $\mathrm{HS}_{\mathrm{n}}{ }^{-}$-treated LasR, but the peak area of Cys ${ }^{188}$-SOH was relatively small. According to the area of the mass spectrogram, $\mathrm{HS}_{\mathrm{n}}{ }^{-}$treatment extensively modified Cys ${ }^{188}$ with 18\% Cys ${ }^{188}$-SSH for Peptide 1c (Figure 6 and Figure S5A) and 31\% Cys $^{188}$-SSSH for Peptide 1d (Figure 6 and Figure S5B); $20 \%$ Cys $^{201}$ and Cys ${ }^{203}$ formed a 
pentasulfur link between the two Cys residues (RS-SSS-SR) (Figure 6 and Figure S6B). A peptide containing a disulfide bond between $\mathrm{Cys}^{201}$ and $\mathrm{Cys}^{203}$ was not found in these samples. The observed and calculated masses of corresponding peptides are given in Table S5. These results show that $\mathrm{HS}_{\mathrm{n}}{ }^{-}$readily modifies LasR.

$\begin{array}{llll} & \text { Peptide la } & \text { Peptide 2a } \\ \text { DTT-treated } & \mathbf{1 8 3} & 192 & 193 \\ & \text { EVLQWCAOGK } & \text { TSWEISVICNCSEANVNFHMGNIR }\end{array}$
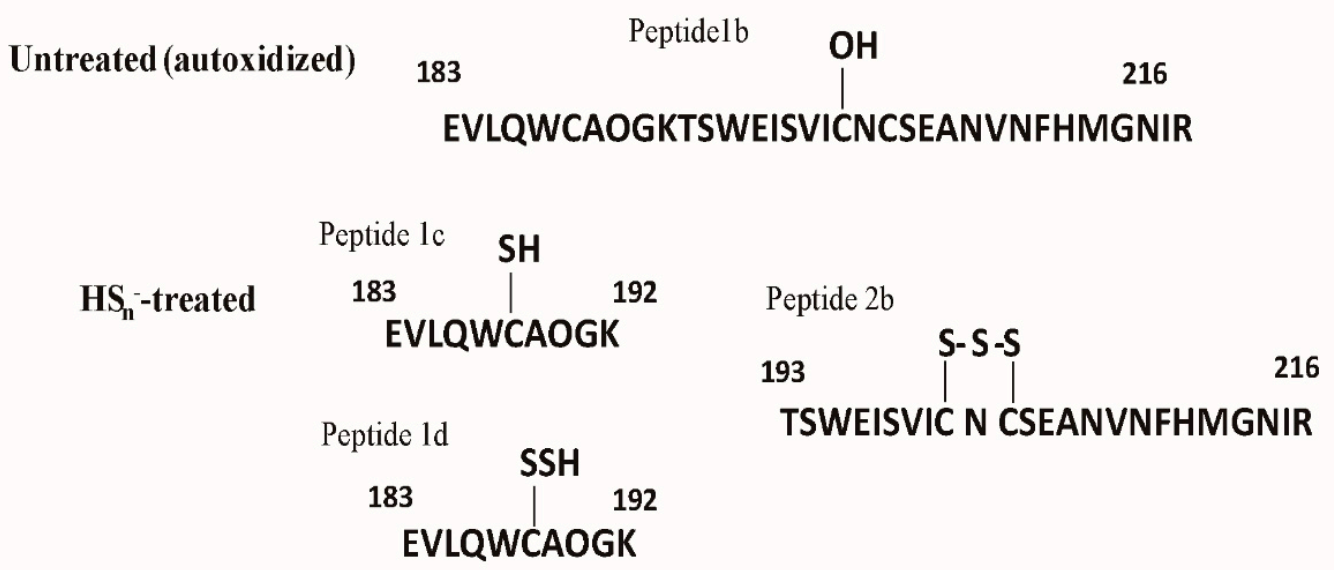

Figure 6. LTQ-Orbitrap tandem mass analysis of $\mathrm{HS}_{\mathrm{n}}{ }^{-}$-reacted LasR. LTQ-Orbitrap tandem mass spectrometry analysis of untreated, DTT-treated, and $\mathrm{HS}_{\mathrm{n}}{ }^{-}$-treated LasR. Peptide 1a and Peptide 2a were found in all samples; Peptide $1 \mathrm{~b}(\mathrm{Cys}-\mathrm{SOH})$ was present in untreated and $\mathrm{HS}_{\mathrm{n}}{ }^{-}$-treated LasR; Peptides 1c (R-SSH), Peptide 1d (R-SSSH), and Peptide 2b (RS-SSS-SR) were detected in $\mathrm{HS}_{\mathrm{n}}{ }^{-}{ }^{-}$treated LasR (Figures S4-S6).

\subsection{The Expression of lasB, rhlR, and lasI Was Affected by Cellular Sulfane Sulfur}

We detected the sulfane sulfur content according to growth stages of $P$. aeruginosa PAO1 in LB medium. The sulfane sulfur contents were high in the mid log phase to stationary phase, and decreased in the declination phase (Figure 7). The expression of lasB, $r h l R$, and lasI, activated by LasR [31], reached the maximum in the stationary phase and decreased sharply in the declination phase. These results indicate that the intracellular level of sulfane sulfur, which is associated with growth phases, regulates LasR activity. 


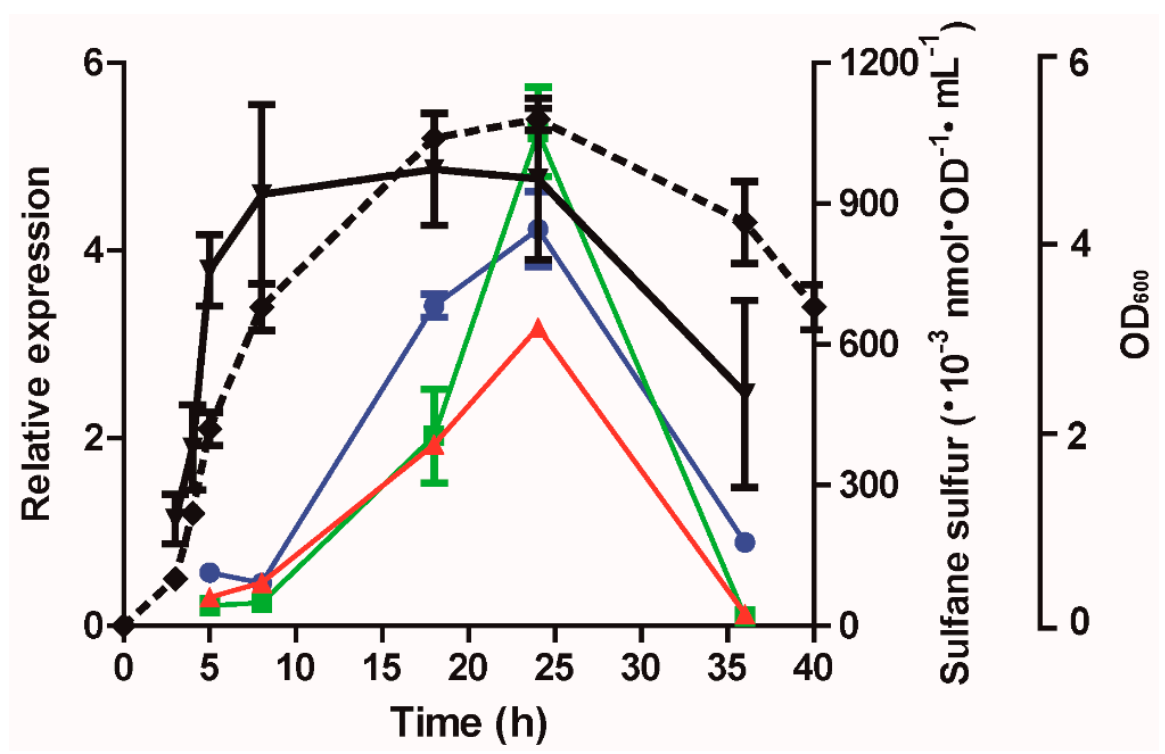

Figure 7. The intracellular levels of sulfane sulfur and the expression of $l a s B, r h l R$, and lasI, which are activated by LasR, were associated with growth phases. Cell density $(\downarrow)$, intracellular sulfane sulfur contents $(\mathbf{\nabla})$, and the transcripts of lasB $(\square), \operatorname{rhlR}(\boldsymbol{\Delta})$, and lasI $(\bullet)$ were analyzed at different growth stages (Dash line, $\mathrm{OD}_{600 \mathrm{~nm}}$ ). The $r p l S$ transcript was used as a reference to calculate the relative expression. Data are averages of three experiments with standard deviations.

\section{Discussion}

In bacteria, well-documented examples of signaling mediated by $\mathrm{H}_{2} \mathrm{~S}$ and sulfane sulfur are usually related to sulfur metabolism $[7,14,53]$. The demonstration that $\mathrm{H}_{2} \mathrm{~S}$ and sulfane sulfur affect quorum sensing in P. aeruginosa $\mathrm{PAO} 1$ provides direct support for the previous prediction that $\mathrm{H}_{2} \mathrm{~S}$ is a signaling message in bacterium [6]. P. aeruginosa PAO1 maintains a high level of cellular sulfane sulfur from the mid log phase to stationary phase (Figure 7). One $\mathrm{mL}$ of E. coli cells at an $\mathrm{OD}_{600 \mathrm{~nm}}$ of 1 corresponds to $3.6 \mu \mathrm{L}$ of cell volume on average, as determined under 22 growth conditions [54]. By using this conversion factor, the maximum cellular sulfane sulfur content in LB grown E. coli cells was calculated to be about $111 \mu \mathrm{M}$, from previously reported data [17], and that in P. aeruginosa PAO1 can be calculated to be to around $250 \mu \mathrm{M}$ from the data in Figure 7. The relatively low level of sulfane sulfur in E. coli explains why the LasR activity was enhanced by adding $\mathrm{H}_{2} \mathrm{~S}$ when the E. coli cells contained both SQR (sulfide:quinone oxidoreductase) and the reporter system (Figure $3 \mathrm{~A}$ ) or by adding $\mathrm{HS}_{\mathrm{n}}{ }^{-}$when the E. coli cells contained only the reporter system (Figure 3B).

Bacteria can metabolize L-cysteine directly into $\mathrm{H}_{2} \mathrm{~S}$ by cysteine desulfhydrases or to produce sulfane sulfur via the concerted actions of L-cysteine aminotransferase and 3-mercaptopyruvate sulfurtransferase [18]. When bacteria possess SQR, they will also oxidize $\mathrm{H}_{2} \mathrm{~S}$ to sulfane sulfur. Sulfane sulfur can be reduced to $\mathrm{H}_{2} \mathrm{~S}$ by cellular thiols, such as glutathione, or by thioredoxin and glutareduxin [20,55], or be further oxidized by PDO (persulfide dioxygenase) to sulfite, which spontaneously reacts with sulfane sulfur to produce thiosulfate $[11,16]$. Since the Pa3K strain and the wild type maintained similar amounts of cellular sulfane sulfur (Figure 1B), the concerted action of SQR and PDO for the oxidation of self-produced $\mathrm{H}_{2} \mathrm{~S}$ did not increase the cellular sulfane sulfur in the wild type. In the Pa3K mutant without $\mathrm{SQR}$ and $\mathrm{PDO}$, the self-produced $\mathrm{H}_{2} \mathrm{~S}$ evaporated into the gas phase, as detected by the filter paper containing lead acetate (Figure 1A). E. coli without SQR and PDO has been shown to mainly use L-cysteine metabolism to maintain cellular sulfane sulfur [18]. Thus, the maintenance of cellular sulfane sulfur requires an active metabolism, and it is not a surprise that the cells in the declination phase contain low sulfane sulfur (Figure 7). 
LasR is a QS master regulator in P. aeruginosa PAO1, and it activates the production of several extracellular products that benefit the population as a whole. Since it is a costly process, P. aeruginosa PAO1 develops strategies to regulate LasR activity, including $3 \mathrm{O}-\mathrm{C}_{12}$-HSL $[35,56], \operatorname{RpoS}[57,58]$, and QscR [38]. Our results suggest that LasR activity is further controlled by cellular sulfane sulfur. Both in vitro and in vivo data indicate that sulfane sulfur-modified LasR is significantly more active than unmodified LasR in the presence of $3 \mathrm{O}-\mathrm{C}_{12}-\mathrm{HSL}$ (Figures 3 and 5). The involvement of sulfane sulfur in regulating LasR-mediated QS makes sense, as it varies during growth, becoming significantly lower in the declination phase (Figure 7), when cells enter survival mode and no long need LasR activity. A model whereby LasR activity is regulated by both $3 \mathrm{O}-\mathrm{C}_{12}-\mathrm{HSL}$ and cellular sulfane sulfur is proposed (Figure 8), allowing the QS to coordinate with the growth phases. When LasR binds $3 \mathrm{O}-\mathrm{C}_{12}-\mathrm{HSL}$, it may bind to the promoter to recruit RNA polymerase for transcription. However, sulfane sulfur-modified LasR is more active than unmodified LasR in promoting transcription. As several virulence factors are activated by LasR, adequate levels of cellular sulfane sulfur are likely important for the pathogenicity of $P$. aeruginosa PAO1 (Figures 2 and 8).

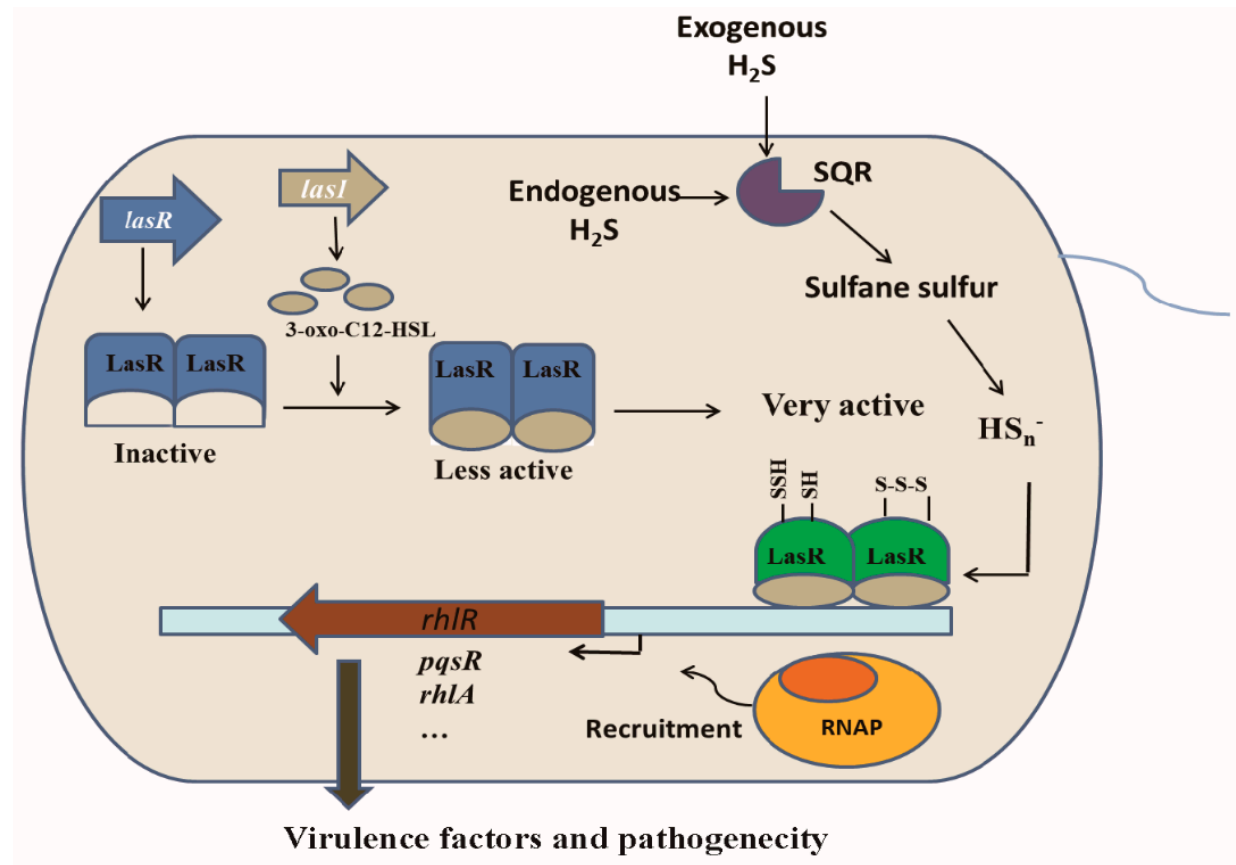

Figure 8. The proposed model of LasR sensing $3 \mathrm{O}-\mathrm{C}_{12}-\mathrm{HSL}$ and sulfane sulfur in P. aeruginosa PAO1. $\mathrm{HS}_{\mathrm{n}}{ }^{-}$modifies LasR and enhances its activity.

Sulfane sulfur has been shown to modify several gene regulators in different forms. FisR of Cupriavidus pinatubonensis JMP134 forms a tetrasulfide crosslinking [7], while CstR of Staphylococcus aureus generates a mixture of di-, tri-, and tetra-sulfur crosslinked species, respectively [9,53]. MexR of Pseudomonas aeruginosa PAO1 mainly forms a disulfide bond, with a small portion of trisulfide [15]. OxyR of Escherichia coli responds to sulfane sulfur stress via persulfidation of OxyR at Cys ${ }^{199}$ [14]. The LasR modification by $\mathrm{HS}_{\mathrm{n}}{ }^{-}$is similar, but different, with persulfidation and trisulfidation of $\mathrm{Cys}^{188}$ and a pentasulfur link between $\mathrm{Cys}^{201}$ and Cys ${ }^{203}$ (Figure 6).

Sulfane sulfur affects gene repressors and activators in different ways in the reported examples to date. The modified repressors, such as CstR, SqrR, and MexR, no longer bind to the target site for the de-repression of the controlled genes $[8,9,15]$. The modification of activators often leads to increased transcription of the target genes. When FisR is modified by sulfane sulfur, it activates $\sigma^{54}$-dependent transcription of sulfide-oxidizing genes for sulfide removal [7]. When OxyR is modified, it increases the transcription of several genes for the removal of high levels of cellular sulfane sulfur [14]. LasR is also a gene activator [34], 
and it becomes more active in initiating transcription of controlled genes (Figure 5). LasR responds to both $\mathrm{H}_{2} \mathrm{O}_{2}$ and sulfane sulfur with opposite effects. $\mathrm{H}_{2} \mathrm{O}_{2}$ treatment of LasR produces a disulfide bond between $\mathrm{Cys}^{201}$ and $\mathrm{Cys}^{203}$, disrupting the LasR binding to its target DNA [40], explaining why LasR is sensitive to oxidative stress $[59,60]$. On the other hand, sulfane sulfur treatment of LasR results in a pentasulfur link between Cys ${ }^{201}$ and Cys $^{203}$, which does not affect the DNA binding (Figure 4) and makes LasR more active in transcription initiation (Figures 3 and 5). The $\mathrm{H}_{2} \mathrm{~S}_{\mathrm{n}}$-modified LasR may be more resistant to $\mathrm{H}_{2} \mathrm{O}_{2}$ damage, but the detailed activation mechanism warrants further investigation.

Garlic extracts that contain organosulfur compounds, such as diallyl disulfides, have antimicrobial activities [61]. The inhibitory activities of diallyl disulfides are in the order tetrasulfide $>$ trisulfide $>$ disulphide $>$ monosulfide [62], implying that the long chain compounds with additional sulfane sulfur are more inhibitory. Furthermore, diallyl disulfide reduces the pathogenicity and biofilm development of P. aeruginosa PAO1 by targeting its QS systems [63]. The inhibitory effect of diallyl disulfide may be in part due to its ability to release sulfane sulfur [64]. As the added diallyl disulfide is up to $1.28 \mathrm{mg}$ per $\mathrm{mL}$ (about $8.8 \mathrm{mM}$ ) [63], the higher concentration may lead to increased levels of sulfane sulfur in P. aeruginosa PAO1. At high concentrations, sulfane sulfur is toxic to microorganisms [14].

\section{Conclusions}

The level of cellular sulfane sulfur varies along with the growth phases of $P$. aeruginosa PAO1. The relatively high level of sulfane sulfur enhances the LasR activity for QS, and a low level inhibits LasR activity, which is likely further reduced by increased oxidative stress, when P. aeruginosa PAO1 enters the declination phase. These findings add a new level of control of LasR activity, beside the autoinducer, $\mathrm{H}_{2} \mathrm{O}_{2}$, and other factors [34-41], representing a fine-tuned activity regulated by various cellular factors. The discovery solidifies a key step in establishing the general signaling role of sulfide and sulfane sulfur in bacteria.

Supplementary Materials: The following are available online at https:/ /www.mdpi.com/article/10 $.3390 /$ antiox10091498/s1. Figure S1. The production of $\mathrm{H}_{2} \mathrm{~S}$ in PAO1 and its mutants. Figure S2. Transcriptomic analysis of PAO1 and the $\mathrm{Pa} \Delta \mathrm{H}_{2} \mathrm{~S}$ mutant. Figure S3. The effect of lasR deletion in P. aeruginosa PAO1 on the growth and pathogenicity. Figure S4. LTQ-Orbitrap tandem mass spectrometry analysis of LasR (Peptides 1a and 1b). Figure S5. LTQ-Orbitrap tandem mass spectrometry analysis of LasR (Peptides 1c and. 1d). Figure S6. LTQ-Orbitrap tandem mass spectrometry analysis of LasR (Peptides $2 \mathrm{a}$ and $2 \mathrm{~b}$ ). Table S1. Strains and plasmids used in this study. Table S2. Primers used in this study. Table S3. List of genes significantly downregulated in $\mathrm{Pa}_{\Delta} \mathrm{H}_{2} \mathrm{~S}$ ( $\geq$ 5-fold) relative to the wild-type strain PAO1. Table S4. List of genes significantly upregulated in $\mathrm{Pa} \Delta \mathrm{H}_{2} \mathrm{~S}$ ( $\geq 5$-fold) relative to the wild-type strain PAO1. Table S5. Mass data from LTQ-Orbitrap tandem mass spectrometry.

Author Contributions: G.X. and C.L. acquired and analyzed the data. K.L. and H.X. contributed to the gene deletion and plasmid construction. H.L. and Y.X. supervised the research. G.X., Y.X. and L.X. designed the study and wrote the manuscript. All authors have read and agreed to the published version of the manuscript.

Funding: The work was financially supported by grants from the National Natural Science Foundation of China (91951202).

Institutional Review Board Statement: Not applicable.

Informed Consent Statement: Not applicable.

Data Availability Statement: Data is contained within the article and supplementary material.

Conflicts of Interest: The authors declare no conflict of interest. 


\section{References}

1. Kimura, H. Hydrogen sulfide and polysulfides as signaling molecules. Proc. Jpn. Acad. Ser. B Phys. Biol. Sci. 2015, 91, 131-159. [CrossRef]

2. Tan, B.H.; Wong, P.T.-H.; Bian, J. Hydrogen sulfide: A novel signaling molecule in the central nervous system. Neurochem. Int. 2010, 56, 3-10. [CrossRef] [PubMed]

3. Módis, K.; Panopoulos, P.; Coletta, C.; Papapetropoulos, A.; Szabo, C. Hydrogen sulfide-mediated stimulation of mitochondrial electron transport involves inhibition of the mitochondrial phosphodiesterase 2A, elevation of cAMP and activation of protein kinase A. Biochem. Pharmacol. 2013, 86, 1311-1319. [CrossRef] [PubMed]

4. Nishida, M.; Sawa, T.; Kitajima, N.; Ono, K.; Inoue, H.; Ihara, H.; Motohashi, H.; Yamamoto, M.; Suematsu, M.; Kurose, H.; et al Hydrogen sulfide anion regulates redox signaling via electrophile sulfhydration. Nat. Chem. Biol. 2012, 8, 714-724. [CrossRef] [PubMed]

5. Mathai, J.C.; Missner, A.; Kugler, P.; Saparov, S.M.; Zeidel, M.L.; Lee, J.K.; Pohl, P. No facilitator required for membrane transport of hydrogen sulfide. Proc. Natl. Acad. Sci. USA 2009, 106, 16633-16638. [CrossRef]

6. Lloyd, D. Hydrogen sulfide: Clandestine microbial messenger? Trends Microbiol. 2006, 14, 456-462. [CrossRef]

7. Li, H.; Li, J.; Lü, C.; Xia, Y.; Xin, Y.; Liu, H.; Xun, L.; Liu, H. FisR activates sigma(54)-dependent transcription of sulfide-oxidizing genes inCupriavidus pinatubonensisJMP134. Mol. Microbiol. 2017, 105, 373-384. [CrossRef]

8. Shimizu, T.; Shen, J.; Fang, M.; Zhang, Y.; Hori, K.; Trinidad, J.C.; Bauer, C.E.; Giedroc, D.P.; Masuda, S. Sulfide-responsive transcriptional repressor SqrR functions as a master regulator of sulfide-dependent photosynthesis. Proc. Natl. Acad. Sci. USA 2017, 114, 2355-2360. [CrossRef]

9. Luebke, J.L.; Shen, J.; Bruce, K.E.; Kehl-Fie, T.; Peng, H.; Skaar, E.P.; Giedroc, D.P. The CsoR-like sulfurtransferase repressor (CstR) is a persulfide sensor in Staphylococcus aureus. Mol. Microbiol. 2014, 94, 1343-1360. [CrossRef]

10. Lu, T.; Cao, Q.; Pang, X.; Xia, Y.; Xun, L.; Liu, H. Sulfane sulfur-activated actinorhodin production and sporulation is maintained by a natural gene circuit in Streptomyces coelicolor. Microb. Biotechnol. 2020, 13, 1917-1932. [CrossRef]

11. Xin, Y.; Liu, H.; Cui, F.; Liu, H.; Xun, L. Recombinant Escherichia coli with sulfide:quinone oxidoreductase and persulfide dioxygenase rapidly oxidises sulfide to sulfite and thiosulfate via a new pathway. Environ. Microbiol. 2016, 18, 5123-5136. [CrossRef]

12. Cherney, M.M.; Zhang, Y.; Solomonson, M.; Weiner, J.H.; James, M.N. Crystal Structure of Sulfide: Quinone Oxidoreductase from Acidithiobacillus ferrooxidans: Insights into Sulfidotrophic Respiration and Detoxification. J. Mol. Biol. 2010, 398, 292-305. [CrossRef] [PubMed]

13. Liu, H.; Fan, K.; Li, H.; Wang, Q.; Yang, Y.; Li, K.; Xia, Y.; Xun, L. Synthetic Gene Circuits Enable Escherichia coli to Use Endogenous H2S as a Signaling Molecule for Quorum Sensing. ACS Synth. Biol. 2019, 8, 2113-2120. [CrossRef] [PubMed]

14. Hou, N.; Yan, Z.; Fan, K.; Li, H.; Zhao, R.; Xia, Y.; Xun, L.; Liu, H. OxyR senses sulfane sulfur and activates the genes for its removal in Escherichia coli. Redox Biol. 2019, 26, 101293. [CrossRef] [PubMed]

15. Xuan, G.; Lü, C.; Xu, H.; Chen, Z.; Li, K.; Liu, H.; Liu, H.; Xia, Y.; Xun, L. Sulfane Sulfur is an intrinsic signal activating MexR-regulated antibiotic resistance in Pseudomonas aeruginosa. Mol. Microbiol. 2020, 114, 1038-1048. [CrossRef] [PubMed]

16. Xia, Y.; Lü, C.; Hou, N.; Xin, Y.; Liu, J.; Liu, H.; Xun, L. Sulfide production and oxidation by heterotrophic bacteria under aerobic conditions. ISME J. 2017, 11, 2754-2766. [CrossRef] [PubMed]

17. Ran, M.; Wang, T.; Shao, M.; Chen, Z.; Liu, H.; Xia, Y.; Xun, L. Sensitive Method for Reliable Quantification of Sulfane Sulfur in Biological Samples. Anal. Chem. 2019, 91, 11981-11986. [CrossRef]

18. Li, K.; Xin, Y.; Xuan, G.; Zhao, R.; Liu, H.; Xia, Y.; Xun, L. Escherichia coli Uses Separate Enzymes to Produce H2S and Reactive Sulfane Sulfur From L-cysteine. Front. Microbiol. 2019, 10, 298. [CrossRef]

19. Shatalin, K.; Shatalina, E.; Mironov, A.; Nudler, E. H2S: A Universal Defense Against Antibiotics in Bacteria. Science 2011, 334, 986-990. [CrossRef]

20. Yadav, P.K.; Yamada, K.; Chiku, T.; Koutmos, M.; Banerjee, R. Structure and Kinetic Analysis of H2S Production by Human Mercaptopyruvate Sulfurtransferase. J. Biol. Chem. 2013, 288, 20002-20013. [CrossRef]

21. Akaike, T.; Ida, T.; Wei, F.-Y.; Nishida, M.; Kumagai, Y.; Alam, M.; Ihara, H.; Sawa, T.; Matsunaga, T.; Kasamatsu, S.; et al. Cysteinyl-tRNA synthetase governs cysteine polysulfidation and mitochondrial bioenergetics. Nat. Commun. 2017, 8, 1177. [CrossRef]

22. Chen, Z.; Zhang, X.; Li, H.; Liu, H.; Xia, Y.; Xun, L. The Complete Pathway for Thiosulfate Utilization in Saccharomyces cerevisiae. Appl. Environ. Microbiol. 2018, 84, e01241-18. [CrossRef]

23. Ida, T.; Sawa, T.; Ihara, H.; Tsuchiya, Y.; Watanabe, Y.; Kumagai, Y.; Suematsu, M.; Motohashi, H.; Fujii, S.; Matsunaga, T.; et al. Reactive cysteine persulfides and S-polythiolation regulate oxidative stress and redox signaling. Proc. Natl. Acad. Sci. USA 2014, 111, 7606-7611. [CrossRef]

24. Winstanley, C.; Fothergill, J.L. The role of quorum sensing in chronic cystic fibrosis Pseudomonas aeruginosainfections. FEMS Microbiol. Lett. 2009, 290, 1-9. [CrossRef]

25. Behzadi, P.; Baráth, Z.; Gajdács, M. It's Not Easy Being Green: A Narrative Review on the Microbiology, Virulence and Therapeutic Prospects of Multidrug-Resistant Pseudomonas aeruginosa. Antibiotics 2021, 10, 42. [CrossRef] 
26. Donadu, M.; Usai, D.; Pinna, A.; Porcu, T.; Mazzarello, V.; Fiamma, M.; Marchetti, M.; Cannas, S.; Delogu, G.; Zanetti, S.; et al. In vitro activity of hybrid lavender essential oils against multidrug resistant strains of Pseudomonas aeruginosa. J. Infect. Dev. Ctries. 2018, 12, 9-14. [CrossRef] [PubMed]

27. Fan, H.; Dong, Y.; Wu, D.; Bowler, M.; Zhang, L.; Song, H. QsIA disrupts LasR dimerization in antiactivation of bacterial quorum sensing. Proc. Natl. Acad. Sci. USA 2013, 110, 20765-20770. [CrossRef]

28. Shao, Y.; Feng, L.; Rutherford, S.T.; Papenfort, K.; Bassler, B. Functional determinants of the quorum-sensing non-coding RNAs and their roles in target regulation. EMBO J. 2013, 32, 2158-2171. [CrossRef] [PubMed]

29. Suneby, E.G.; Herndon, L.R.; Schneider, T.L. Pseudomonas aeruginosa LasR.DNA Binding Is Directly Inhibited by Quorum Sensing Antagonists. ACS Infect. Dis. 2017, 3, 183-189. [CrossRef] [PubMed]

30. Medina, G.; Juárez, K.; Díaz, R.; Soberón-Chávez, G. Transcriptional regulation of Pseudomonas aeruginosa rhlR, encoding a quorum-sensing regulatory protein. Microbiology 2003, 149, 3073-3081. [CrossRef]

31. Gilbert, K.B.; Kim, T.H.; Gupta, R.; Greenberg, E.P.; Schuster, M. Global position analysis of the Pseudomonas aeruginosa quorumsensing transcription factor LasR. Mol. Microbiol. 2009, 73, 1072-1085. [CrossRef] [PubMed]

32. Schuster, M.; Urbanowski, M.L.; Greenberg, E.P. Promoter specificity in Pseudomonas aeruginosa quorum sensing revealed by DNA binding of purified LasR. Proc. Natl. Acad. Sci. USA 2004, 101, 15833-15839. [CrossRef] [PubMed]

33. McCready, A.; Paczkowski, J.E.; Henke, B.R.; Bassler, B.L. Structural determinants driving homoserine lactone ligand selection in the Pseudomonas aeruginosa LasR quorum-sensing receptor. Proc. Natl. Acad. Sci. USA 2019, 116, 245-254. [CrossRef]

34. Sappington, K.J.; Dandekar, A.A.; Oinuma, K.-I.; Greenberg, E.P. Reversible Signal Binding by the Pseudomonas aeruginosa Quorum-Sensing Signal Receptor LasR. mBio 2011, 2, e00011-11. [CrossRef]

35. Whiteley, M.; Lee, K.M.; Greenberg, E.P. Identification of genes controlled by quorum sensing in Pseudomonas aeruginosa. Proc. Natl. Acad. Sci. USA 1999, 96, 13904-13909. [CrossRef]

36. Schuster, M.; Lostroh, P.; Ogi, T.; Greenberg, E.P. Identification, Timing, and Signal Specificity of Pseudomonas aeruginosa Quorum-Controlled Genes: A Transcriptome Analysis. J. Bacteriol. 2003, 185, 2066-2079. [CrossRef]

37. Scholz, R.L.; Greenberg, E.P. Positive Autoregulation of an Acyl-Homoserine Lactone Quorum-Sensing Circuit Synchronizes the Population Response. mBio 2017, 8, e01079-17. [CrossRef] [PubMed]

38. Ding, F.; Oinuma, K.-I.; Smalley, N.E.; Schaefer, A.L.; Hamwy, O.; Greenberg, E.P.; Dandekar, A.A. The Pseudomonas aeruginosa Orphan Quorum Sensing Signal Receptor QscR Regulates Global Quorum Sensing Gene Expression by Activating a Single Linked Operon. mBio 2018, 9, e01274-18. [CrossRef]

39. Yan, H.; Asfahl, K.L.; Li, N.; Sun, F.; Xiao, J.; Shen, D.; Dandekar, A.A.; Wang, M. Conditional quorum-sensing induction of a cyanide-insensitive terminal oxidase stabilizes cooperating populations of Pseudomonas aeruginosa. Nat. Commun. 2019, 10, 4999. [CrossRef]

40. Kafle, P.; Amoh, A.N.; Reaves, J.M.; Suneby, E.G.; Tutunjian, K.A.; Tyson, R.L.; Schneider, T.L. Molecular Insights into the Impact of Oxidative Stress on the Quorum-Sensing Regulator Protein LasR. J. Biol. Chem. 2016, 291, 11776-11786. [CrossRef]

41. Chuang, S.K.; Vrla, G.D.; Fröhlich, K.; Gitai, Z. Surface association sensitizes Pseudomonas aeruginosa to quorum sensing. Nat. Commun. 2019, 10, 4118. [CrossRef]

42. Essar, D.W.; Eberly, L.; Hadero, A.; Crawford, I.P. Identification and characterization of genes for a second anthranilate synthase in Pseudomonas aeruginosa: Interchangeability of the two anthranilate synthases and evolutionary implications. J. Bacteriol. 1990, 172, 884-900. [CrossRef] [PubMed]

43. Kamyshny, A. Improved cyanolysis protocol for detection of zero-valent sulfur in natural aquatic systems. Limnol. Oceanogr. Methods 2009, 7, 442-448. [CrossRef]

44. Lü, C.; Xia, Y.; Liu, D.; Zhao, R.; Gao, R.; Liu, H.; Xun, L. Cupriavidus necator H16 Uses Flavocytochrome c Sulfide Dehydrogenase to Oxidize Self-Produced and Added Sulfide. Appl. Environ. Microbiol. 2017, 83, e01610-17. [CrossRef] [PubMed]

45. Harighi, B. Genetic evidence for CheB- and CheR-dependent chemotaxis system in A. tumefaciens toward acetosyringone. Microbiol. Res. 2009, 164, 634-641. [CrossRef]

46. Kolluru, G.; Shen, X.; Bir, S.C.; Kevil, C.G. Hydrogen sulfide chemical biology: Pathophysiological roles and detection. Nitric Oxide Biol. Chem. 2013, 35, 5-20. [CrossRef]

47. Bibli, S.-I.; Luck, B.; Zukunft, S.; Wittig, J.; Chen, W.; Xian, M.; Papapetropoulos, A.; Hu, J.; Fleming, I. A selective and sensitive method for quantification of endogenous polysulfide production in biological samples. Redox Biol. 2018, 18, 295-304. [CrossRef]

48. Cao, Q.; Wang, Y.; Chen, F.; Xia, Y.; Lou, J.; Zhang, X.; Yang, N.; Sun, X.; Zhang, Q.; Zhuo, C.; et al. A Novel Signal Transduction Pathway that Modulates rhl Quorum Sensing and Bacterial Virulence in Pseudomonas aeruginosa. PLOS Pathog. 2014, 10, e1004340. [CrossRef]

49. Filiatrault, M.J.; Picardo, K.F.; Ngai, H.; Passador, L.; Iglewski, B.H. Identification of Pseudomonas aeruginosa Genes Involved in Virulence and Anaerobic Growth. Infect. Immun. 2006, 74, 4237-4245. [CrossRef]

50. Xia, Y.Z.; Chu, W.Q.; Qi, Q.S.; Xun, L.Y. New insights into the QuikChange (TM) process guide the use of Phusion DNA polymerase for site-directed mutagenesis. Nucleic Acids Res. 2015, 43, e12. [CrossRef]

51. Shen, J.; Peng, H.; Zhang, Y.; Trinidad, J.C.; Giedroc, D.P. Staphylococcus aureus sqr Encodes a Type II Sulfide: Quinone Oxidoreductase and Impacts Reactive Sulfur Speciation in Cells. Biochemistry 2016, 55, 6524-6534. [CrossRef] [PubMed] 
52. Bottomley, M.J.; Muraglia, E.; Bazzo, R.; Carfi, A. Molecular Insights into Quorum Sensing in the Human Pathogen Pseudomonas aeruginosa from the Structure of the Virulence Regulator LasR Bound to Its Autoinducer. J. Biol. Chem. 2007, 282, 13592-13600. [CrossRef]

53. Giedroc, D.P. A new player in bacterial sulfide-inducible transcriptional regulation. Mol. Microbiol. 2017, 105, 347-352. [CrossRef]

54. Volkmer, B.; Heinemann, M. Condition-Dependent Cell Volume and Concentration of Escherichia coli to Facilitate Data Conversion for Systems Biology Modeling. PLoS ONE 2011, 6, e23126. [CrossRef]

55. Dóka, É.; Pader, I.; Bíró, A.; Johansson, K.; Cheng, Q.; Ballagó, K.; Prigge, J.R.; Pastor-Flores, D.; Dick, T.P.; Schmidt, E.E.; et al. A novel persulfide detection method reveals protein persulfide- and polysulfide-reducing functions of thioredoxin and glutathione systems. Sci. Adv. 2016, 2, e1500968. [CrossRef] [PubMed]

56. Passador, L.; Cook, J.M.; Gambello, M.J.; Rust, L.; Iglewski, B.H. Expression of Pseudomonas aeruginosa virulence genes requires cell-to-cell communication. Science 1993, 260, 1127-1130. [CrossRef] [PubMed]

57. Winzer, K.; Falconer, C.; Garber, N.C.; Diggle, S.P.; Camara, M.; Williams, P. The Pseudomonas aeruginosa Lectins PA-IL and PA-IIL Are Controlled by Quorum Sensing and by RpoS. J. Bacteriol. 2000, 182, 6401-6411. [CrossRef] [PubMed]

58. Schuster, M.; Greenberg, E.P. Early activation of quorum sensing in Pseudomonas aeruginosa reveals the architecture of a complex regulon. BMC Genom. 2007, 8, 287. [CrossRef] [PubMed]

59. Deng, X.; Weerapana, E.; Ulanovskaya, O.; Sun, F.; Liang, H.; Ji, Q.; Ye, Y.; Fu, Y.; Zhou, L.; Li, J.; et al. Proteome-wide Quantification and Characterization of Oxidation-Sensitive Cysteines in Pathogenic Bacteria. Cell Host Microbe 2013, 13, 358-370. [CrossRef]

60. Zhou, H.; Wang, M.; Smalley, N.E.; Kostylev, M.; Schaefer, A.L.; Greenberg, E.P.; Dandekar, A.A.; Xu, F. Modulation of Pseudomonas aeruginosa Quorum Sensing by Glutathione. J. Bacteriol. 2019, 201, e00685-00618. [CrossRef]

61. Casella, S.; Leonardi, M.; Melai, B.; Fratini, F.; Pistelli, L. The Role of Diallyl Sulfides and Dipropyl Sulfides in the In Vitro Antimicrobial Activity of the Essential Oil of Garlic, Allium sativum L., and Leek, Allium porrum L. Phytother. Res. 2013, 27, 380-383. [CrossRef] [PubMed]

62. Tsao, S.-M.; Yin, M.-C. In-vitro antimicrobial activity of four diallyl sulphides occurring naturally in garlic and Chinese leek oils. J. Med. Microbiol. 2001, 50, 646-649. [CrossRef] [PubMed]

63. Li, W.-R.; Ma, Y.-K.; Shi, Q.-S.; Xie, X.-B.; Sun, T.-L.; Peng, H.; Huang, X.-M. Diallyl disulfide from garlic oil inhibits Pseudomonas aeruginosa virulence factors by inactivating key quorum sensing genes. Appl. Microbiol. Biotechnol. 2018, 102, 7555-7564. [CrossRef]

64. Nakamoto, M.; Kunimura, K.; Suzuki, J.-I.; Kodera, Y. Antimicrobial properties of hydrophobic compounds in garlic: Allicin, vinyldithiin, ajoene and diallyl polysulfides. Exp. Ther. Med. 2020, 19, 1550-1553. [CrossRef] [PubMed] 